\title{
ASSOCIATIONS BETWEEN MOTIVATION, FACILITY, AND WORK PERFORMANCE AMONG MIDWIVES IN ANTENATAL CARE IN CENTRAL JAVA
}

\author{
Titis Eka Gusti1), Didik Tamtomo²), Bhisma Murti) \\ 1)Masters Program in Public Health, Universitas Sebelas Maret \\ 2)Faculty of Medicine, Universitas Sebelas Maret
}

\begin{abstract}
Background: Earlier studies have shown motivation is a driver to health worker performance in hospitals. Motivation of employees determines the level of input that employees will put in the organization to commit to good performance. Either intrinsic or extrinsic motivation contributes to employee satisfaction and thus enhances performance and productivity. Studies into the association between motivation and work performance among midwives in Indonesia, however, are scanty. This study aimed to estimate the associations between motivation, facility, and work performance among midwives in antenatal care.
\end{abstract}

Subjects and Methods: This was a cross sectional study carried out in 25 Community Health Centers in Karanganyar regency and Surakarta, Central Java, from April to May 2018. A sample of 200 midwives was selected for this study by stratified random sampling. The dependent variable was work performance. The independent variables were motivation and facility. The data were collected by questionnaire. The data were analyzed by a multiple linear regression model.

Results: Midwife work performance in antenatal care was positively associated with motivation $(\mathrm{b}=0.23 ; 95 \% \mathrm{CI}=0.11$ to $0.34 ; \mathrm{p}<0.001)$ and facility $(\mathrm{b}=0.51$; $95 \% \mathrm{CI}=0.46$ to $0.55 ; \mathrm{p}<0.001$ ). Adjusted $\mathrm{R}^{2}=85.2 \%$

Conclusion: Midwife work performance in antenatal care is positively associated with motivation and facility.

Keywords: motivation, facility, work performance, midwife, antenatal care

\section{Correspondence:}

Titis Eka Gusti. Masters Program in Public Health, Universitas Sebelas Maret. Jl. Ir. Sutami No. 36A, Surakarta 57126, Central Java.

Email: titisekagusti@gmail.com. Mobile: +6282264477979.

The 4th International Conference on Public Health

Best Western Premier Hotel, Solo, Indonesia, August 29-30, 2018 | 278 https://doi.org/10.26911/theicph.2018.04.47 